\title{
The War On Drugs And Crime Rates
}

Yassaman Saadatmand, Armstrong Atlantic State University, USA

Michael Toma, Armstrong Atlantic State University, USA

Jeremy Choquette, Armstrong Atlantic State University, USA

\begin{abstract}
This paper analyzes the effects of the "War on Drugs" on crime rates. Many in the field of law enforcement believe that incarcerating drug offenders reduces crime. However, time-series analysis of four types of crime rates in the United States does not support this view. Using seven explanatory variables, including federal spending on the Drug Enforcement Agency, incarceration rates for drug offenders, and abortion rates, the results suggest the incarceration of drug offenders causes a crowding-out effect in prisons, releasing non-drug offenders and thereby potentially increasing, rather than reducing crime.
\end{abstract}

Keywords: War On Drugs; Drug-Related Incarceration; Abortion; Crime Rates; Drug Enforcement Agency

\section{INTRODUCTION}

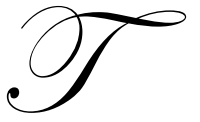

his paper studies the effects of the "War on Drugs" as measured by mandatory sentencing laws, federal spending on the Drug Enforcement Administration (DEA), and drug related incarcerations on crime rates. For many years, politicians have been enamored with the idea that increasing incarceration rates for drug offenders will decrease the crime rate. "You don't have to do a scientific study to determine what every law enforcement officer in America knows: drugs breed crime." ${ }^{1}$ This notion has led to a rise in prison construction, the imposition of mandatory sentencing, and the passage of "three-strikes" laws to name a few.

In contrast, many economists have supported the decriminalization of drugs, in particular marijuana, and enumerated various social and economic costs associated with their prohibition. In fact, some argue that the prohibition of drugs will create more crime than it will prevent. Mandatory minimum sentencing laws, for instance, create a crowding-out effect in prisons, where non-drug offenders will be released early from prisons. There is a rich literature analyzing the causes and repercussions of drug criminalization and the criminal justice system's response to the drug trade.

This paper will analyze the effects of the war on drugs on crime rates, quantifying the war on drugs with variables characterizing the Anti-Drug Act and the density of drug-related convicts in the prison system. The paper is divided into five parts: a brief background on the "War on Drugs," literature review, model and explanation of variables, estimation and results, and conclusion.

\section{THE WAR ON DRUGS}

Although the U.S. government has battled drug abuse for decades, it was President Eisenhower's administration that took the first aggressive stance against drugs. In 1954, President Eisenhower coined the term "War on Drugs" when he established the Interdepartmental Committee on Narcotics. However, the term "War on Drugs" was not widely used until President Nixon created the Drug Enforcement Administration (DEA) in 1973 to announce "an all-out global war on the drug menace." In the 1980s, President Reagan continued with anti-drug policies, possibly stronger than any of his predecessors. During his presidency, numerous anti-drug policies and campaigns were enacted to help prevent drug abuse. In 1986, the Anti-Drug Act attempted to control the crack

${ }_{1}^{1}$ Governor Frank Keating of Oklahoma, http://www.ok.gov/osfdocs/nr10296.html

${ }^{2}$ http://www.time.com/time/world/article/0,8599,1887488,00.html 
cocaine epidemic, which was a relatively inexpensive drug to produce and marketed to low income black communities. This act established mandatory minimum sentencing laws for the trafficking and possession of illegal drugs. In 2002, the Bush administration's goal of reducing all illegal drug use by $25 \%$ led to unprecedented numbers of marijuana-related arrests. ${ }^{3}$

In 2009, after almost four decades of the US government's declaration of a "War on Drugs," the Obama administration's drug czar declared his intention of banishing the concept that the U.S. is fighting "a war on drugs." Rather than focusing on the criminalization of drug, the administration's new perspective is to treat the issue as a matter of public health, placing greater emphasis on treatment instead of incarceration. This new direction might be an initial step on the path that would bring the war on drugs to an end. ${ }^{4}$

\section{PREVIOUS RESEARCH}

Becker (1968) argued that criminals are rational and self-interested agents whose behavior must be understood within the framework of any decisions made under uncertainty and constraints set forth by the government. Akerlof and Yellen (1994) further refined this approach, suggesting that criminals know the probability of being caught, which is a function of law enforcement and the behavior of the community. Lochner (2004) introduced education and training in an opportunity cost model of human capital and argued that education increased earnings and consequently raised the costs of planning and engaging in crime.

The direct relationship between incarceration and crime rates has attracted interest in the literature. For some, including Becker (1968), imprisonment can serve as a deterrent as the individuals consider the expected costs and benefits associated with criminal activities. The unsurprising conclusion is that the "more severe punishment raises the costs of illegal behavior, thereby convincing at least some individuals to refrain from crime" (DeFina, et al.,2002, p.636). On the other hand, others suggest that incarceration in fact may increase crime rates by "weakening the controls on crime imposed by individuals, families, and communities" (DeFina, et al.,2002, p.636). It is argued that the effects of the imprisonment on families are devastating which in itself may lead to increases in crime (Rose and Clear, 1998, p. 441.) Also, greater imprisonment decreases community cohesiveness by "reducing the likelihood that ex-convicts obtain steady, decent jobs" (DeFina, et al., 2002, p.636). Other research focuses on the relationship between the war on drugs and criminal activities. Friedman (1991), for instance, attributed the rise in homicide rates in the United States to the "War on Drugs." He also argued that such a war has led to the destruction of many communities in the United States. Friedman favored the decriminalization of drugs.

You are not mistaken in believing that drugs are a scourge that is devastating our society. You are not mistaken in believing that drugs are tearing asunder our social fabric, ruining the lives of many young people, and imposing heavy costs on some of the most disadvantaged among us.... Your mistake is failing to recognize that the very measures you favor are a major source of the evils you deplore. Of course the problem is demand, but it is not only demand, it is demand that must operate through repressed and illegal channels. Illegality creates obscene profits that finance the murderous tactics of the drug lords; illegality leads to the corruption of law enforcement officials; illegality monopolizes the efforts of honest law forces so that they are starved for resources to fight the simpler crimes of robbery, theft and assault. (Friedman 1990, P.1)

Similarly, Chambliss (1995) asserted that the "War on Drugs" produced many negative consequences. Among them is the increasing number of people in prison; with over fifty percent of offenders being those that should not be considered in the category of committing "very serious crimes." According to him, the "War on Drugs" has also produced another war: the war on the minority youth of the underclass. Kuziemko and Levitt (2004) also maintained that while the number of people incarcerated on drug-related offenses increased 15 times from 1980 to 2000 , the overall impact on the reduction in violent and property crime has been very small, suggesting that the dramatic increase in drug imprisonment was not cost effective. There are those who stress that the "War on Drugs" contributed to a rise in violent crime because the war substantially increased the prices of drugs and created a highly profitable and violent black market (Cundiff, 2000). Benson and Rasmussen (1996) argued that crime leads to drug

\footnotetext{
${ }^{3}$ http://www.time.com/time/world/article/0,8599,1887488,00.html

4 http://online.wsj.com/article/SB124225891527617397.html 
use and not the reverse. Not only has the drug war failed to reduce violent and property crime, but it has also shifted criminal justice resources (the police, courts, prisons, probation officers, etc.) away from directly fighting violent and property crime. The drug war has put citizens' lives and property at greater risk.

Recently, a group of economists has introduced the idea that the legalization of abortion is a significant explanatory factor in the changes in crime rates. Donohue and Levitt (2001) for instance, in studying the decline in crime rates in the 1990s, offer evidence that legalized abortion has contributed significantly to crime reduction. They argue that crime began to fall roughly eighteen years after the legalization of abortion, and the states that allowed abortion earlier than the rest of the country witnessed a reduction earlier than other states. Levitt (2004) provides four factors that explain the decline of crime in the 1990s. These factors include increases in the number of police, the rising prison population, the receding crack cocaine epidemic, and the legalization of abortion.

\section{MODEL AND VARIABLES}

The focus of this paper is the impact of the "War on Drugs" on crime rates. The period of study covers 1970 to 2009 in the United States. Four categories of crime rates (CRIME INDICATOR) are considered: total crime, violent crime, property crime and burglaries. These variables are measured as a rate per 100,000 inhabitants. The data for these four variables were compiled from the United States Bureau of Justice Statistics.

The percentage of inmates convicted on drug related offenses (PRIS) and federal spending on the Drug Enforcement Administration (DEA) are used as rough proxy variables to characterize the intensity of the "War on Drugs." Also included are five other explanatory variables: GDP per capita (GDP), unemployment rate (UE), abortion rate (ABRT), the 1986 Anti-Drug Act (1986DRG) and the price of cocaine (COKE). The general form of the equation is:

$$
\text { CRIME INDICATOR }=\beta_{0}+\beta_{1} \text { PRIS }+\beta_{2} \mathrm{ABRT}+\beta_{3} \mathrm{COKE}+\beta_{4} \mathrm{GDP}+\beta_{5} \mathrm{UE}+\beta_{6} \mathrm{DEA}+\beta_{7} 1986 \mathrm{DRG}
$$

PRIS is the percentage of the federal prison population that has been incarcerated for drug-related offenses. If the war on drugs reduced crime rates, the expected coefficient of this variable is negative. DEA is the percentage of the annual Federal Justice budget that has been granted to the Drug Enforcement Agency. The source of this variable is the DEA webpage. Again, if the "War on Drugs" has been effective, the expected sign on the coefficient is negative.

GDP is real per capita GDP (constant 2005 dollars), and is expected to be negatively related to crime rates. This variable enters the model in its first difference, focusing attention on the notion that a positive change in the source of legitimate income could reduce the incentive to engage in criminal enterprises. The source of the data is the Bureau of Economic Analysis, U.S. Department of Commerce.

UE is the unemployment rate. This variable displays a periodic trend, so the sine of this variable was computed and used in the regression model. As labor market opportunities for lawful sources of income decrease, individuals are more likely to turn to non-lawful sources of income. The expected sign of this variable's coefficient is positive. ${ }^{5}$

ABRT is measured as the abortion rate per one thousand live births. This was obtained from the Centers for Disease Control and United Nations. Based on Levitt (2004), the expected sign of this variable's coefficient is negative. This variable is lagged twenty years and thus ranges from 1950 to 1989.

1986DRG is a binomial regressor used to account for the years that the 1986 Anti-Drug Act was in place. The bill became law in 1986, and aggressively targeted the possession and trafficking of crack cocaine. If the bill was effective in decreasing crime, this variable should enter the model with a negative sign. Alternatively, if critics of the "War on Drugs" are correct, this law will increase out-of-prison crime rates.

${ }^{5}$ Following Johnson (2012) and Chu (1998), the sine of a variable displaying a periodic trend can be included in the linear regression model. 
COKE is the average reported price (in dollars) of less than two grams of cocaine. This data was taken from the National Criminal Justice Reporting Services. Being relatively more expensive than most other drugs, cocaine is the drug of choice for relatively high income individuals. Therefore, higher prices potentially imply higher profit margins and may consequently cause increased crime.

Descriptive statistics are provided in Table 1.

Table 1

\begin{tabular}{|l|c|c|c|c|c|c|c|c|c|c|c|}
\hline \multicolumn{10}{|c|}{ Descriptive Statistics } \\
\hline & TOTAL & BRGLY & VLNT & PROP & COKE & UE & PRIS & ABRT & DEA & GDP & 1986 DRG \\
\hline Mean & 4914 & 1135.6 & 555.7 & 4358 & 521.5 & -0.23 & 43.14 & 175.31 & 907.2 & 529.1 & 0.57 \\
\hline Median & 5114 & 1195.2 & 538.4 & 4596 & 293.2 & -0.49 & 51.05 & 29.25 & 713.5 & 633.8 & 1 \\
\hline Max & 5950 & 1684 & 758.1 & 5353 & 2494 & 0.98 & 61.3 & 434.6 & 2494 & 1448 & 1 \\
\hline Min & 3669 & 722 & 396 & 3211 & 105.5 & -0.99 & 16.9 & 0.07 & 197.9 & -668.7 & 0 \\
\hline
\end{tabular}

\section{RESULTS}

The results of the time series analysis are presented in Table $2 .{ }^{6}$ PRIS, the percentage of the federal prison population incarcerated for drug related offenses, is significant and positive for total crime, property crime and burglary. The positive coefficients are consistent with Benson's, et al (1996) argument that as a result of mandatory minimum sentencing laws, the sentencing discretion of judges is removed and it forces the drug offender into incarceration. When prisons become crowded with drug offenders, jailers must make room for them by releasing non-drug offenders. The DEA budget had a negative and significant effect on all categories of crime rates, and may indicate that expenditures on the DEA decrease out-of-prison crime. The binary variable for the Anti-Drug Act of 1986 is positive and significant at conventional levels in 3 of the 4 models, the exception being in the model for burglary rates. The positive coefficient suggests the effects of the Act are statistically associated with increased crimes, the opposite of what lawmakers had intended.

Abortion rates, as expected, have a negative effect on crime rates; it was significant when regressed against all crime rates with the exception of violent crime. This is consistent with Levitt's research that abortion decreases crime. Real per-capita GDP, as expected, has a negative and significant effect on all crime rates, indicating that with an increase in the number of legitimate avenues for income, the incentive to commit crime falls. The price of cocaine has a negative and significant effect on total crime, property crime, and burglary rates. However, it has a significant and positive effect on violent crime rates, suggesting the possibility that an increase in the price of cocaine can lead to the commission of more violent crimes, perhaps as a result of disputes over the drug.

One implication of these results is that the Anti-Drug Act and increasing density of drug-related convicts in the nation's prisons may be contributing to increased crime rates. However, the DEA budget, calculated as the proportion of the annual Federal Justice budget granted to the DEA, has a negative and significant effect on all crime rates.

With respect to policy implications, these results indicate that laws enacted as a result of the "War on Drugs" have been detrimental to society, increasing crime in the four categories considered. The mechanism through which this appears to happen is that the increasing density of drug-related convicts in the prison system crowds out other criminals who may be more likely to commit a victimized crime. This research suggests that incarceration of drug offenders may increase other types of crime. Incarceration of drug-offenders, then, is ineffective as a sole means by which to reduce the use of illicit drugs and their potential adverse effects on society.

\footnotetext{
${ }^{6}$ The variables were tested using the Augmented Dickey Fuller statistic for the existence of a unit-root. All ADF statistics fell below the critical values at the $1 \%$ significance level, thus allowing for the usage in the level, rather than first difference. Autocorrelation in the model was addressed by using one-year and two-year autoregressive (AR) terms. Both AR terms were significant at the $1 \%$ level in all four models. The Box-Pierce Q-statistic has a critical value of 7.78 with four degrees of freedom at the $10 \%$ level, and the statistic indicates the model is free of significant autocorrelation.
} 


\begin{tabular}{|c|c|c|c|c|}
\hline & Total Crimes & $\begin{array}{c}\text { Table } 2 \\
\text { Property }\end{array}$ & Violence & Burglary \\
\hline Constant & $\begin{array}{l}5002.7 \\
(13.28) * * *\end{array}$ & $\begin{array}{l}4503.8 \\
(15.6)^{* * *}\end{array}$ & $\begin{array}{l}710.5 \\
(7.02)^{* * *}\end{array}$ & $\begin{array}{l}1553.0 \\
(21.88)^{* * * *}\end{array}$ \\
\hline COKE & $\begin{array}{l}-0.08 \\
(-2.63) * *\end{array}$ & $\begin{array}{l}-0.08 \\
(-2.61) * *\end{array}$ & $\begin{array}{l}0.002 \\
(1.93)^{* *}\end{array}$ & $\begin{array}{l}-.012 \\
(-1.47)\end{array}$ \\
\hline UE & $\begin{array}{l}150.4 \\
(2.58)^{* *}\end{array}$ & $\begin{array}{l}139.4 \\
(2.56)^{* *}\end{array}$ & $\begin{array}{l}14.5 \\
(2.59) * *\end{array}$ & $\begin{array}{l}47.1 \\
(1.8)^{*}\end{array}$ \\
\hline PRIS & $\begin{array}{l}19.95 \\
(2.58)^{* *}\end{array}$ & $\begin{array}{l}16.86 \\
(2.22)^{* * *}\end{array}$ & $\begin{array}{l}-0.74 \\
(-.699)\end{array}$ & $\begin{array}{l}2.48 \\
(1.68)^{*}\end{array}$ \\
\hline $\mathrm{ABRT}$ & $\begin{array}{l}-2.6 \\
(-3.97) * * *\end{array}$ & $\begin{array}{l}-2.31 \\
(-4.32) * * *\end{array}$ & $\begin{array}{l}-0.15 \\
(-.65)^{* * *}\end{array}$ & $\begin{array}{l}-0.77 \\
(-7.38) * * *\end{array}$ \\
\hline DEA & $\begin{array}{l}-0.36 \\
(-2.31)^{* *}\end{array}$ & $\begin{array}{l}-0.34 \\
(-2.43)^{* *}\end{array}$ & $\begin{array}{l}-0.34 \\
(-2.43) * *\end{array}$ & $\begin{array}{l}-0.13 \\
(4.7)^{* * *}\end{array}$ \\
\hline GDP & $\begin{array}{l}-0.18 \\
(-5.65) * * *\end{array}$ & $\begin{array}{l}-0.16 \\
(-5.71) * * *\end{array}$ & $\begin{array}{l}-0.019 \\
(-5.64) * * *\end{array}$ & $\begin{array}{l}-0.047 \\
(-3.34)^{* * *}\end{array}$ \\
\hline 1986DRG & $\begin{array}{l}144.4 \\
(2.70)^{* *}\end{array}$ & $\begin{array}{l}108.65 \\
(2.09)^{* * *}\end{array}$ & $\begin{array}{l}36.75 \\
(3.02)^{* * *}\end{array}$ & $\begin{array}{l}6.35 \\
(0.38)\end{array}$ \\
\hline $\mathrm{AR}(1)$ & $\begin{array}{l}1.29 \\
(9.35)^{* * *}\end{array}$ & $\begin{array}{l}1.25 \\
(8.81)^{* * *}\end{array}$ & $\begin{array}{l}1.59 \\
(14.57) * * *\end{array}$ & $\begin{array}{l}1.04 \\
(8.71) * * *\end{array}$ \\
\hline $\mathrm{AR}(2)$ & $\begin{array}{l}-0.55 \\
(-3.72)^{* * *}\end{array}$ & $\begin{array}{l}-0.57 \\
(-3.98) * * *\end{array}$ & $\begin{array}{l}-0.64 \\
(-6.02) * * *\end{array}$ & $\begin{array}{l}-0.53 \\
(-4.64) * * *\end{array}$ \\
\hline R-square & 0.98 & 0.98 & 0.98 & 0.99 \\
\hline Adj R-Square & 0.97 & 0.97 & 0.96 & 0.98 \\
\hline F-statistic & 131.1 & 135.91 & 114.13 & 193.31 \\
\hline Q-Stat & 3.34 & 3.19 & 3.73 & 5.0 \\
\hline $\mathrm{N}$ & 36 & 36 & 36 & 36 \\
\hline
\end{tabular}

\section{CONCLUSION}

This research suggests that the war on drugs, as measured by the percentage of the federal prison population incarcerated for drug related offenses and the existence of the 1986 Anti-Drug Act, may not have led to a reduction in crime rates. In fact, the results suggest the opposite. However, as the share of the annual Federal Justice budget that has been granted to the DEA increases, crime rates tend to fall.

\section{AUTHOR INFORMATION}

Yassaman Saadatmand is professor and department head of economics Armstrong Atlantic State University. E-mail: yassaman.saadatmand@armstrong.edu

Michael Toma is a professor of economics and directs the Center for Regional Analysis at Armstrong. E-mail: michael.toma@armstrong.edu, Corresponding author.

Jeremy Choquette is a senior level economics student graduating in May 2012. E-mail: jc8866@stu.armstrong.edu

\section{REFERENCES}

1. Akerlof, George, A., and Janet Yellen, (1994), "Gang Behavior, Law Enforcement, and Community Values." Values and Public Policy, edited by Aron, Henry J., Thomas E. Mann, and Timothy Taylor, Brookings Institute, pp. 173-209.

2. Becker, Gary (1968), "Crime and Punishment: An Economic Approach," Journal of Political Economy, 73, pp. 169-217. 
3. Benson, Bruce and David Rasmussen (1996), "Illicit Drugs and Crime," Independent Institute, available at http://www.independent.org/publications/policy reports/detail.asp?type=summary\&id=2

4. Chambliss, William J, (1995), "Another Lost War: The Costs and Consequences of Drug Prohibition," Social Justice, 22.2, pp. 101-124.

5. Chu, Fong-Lin, (1998), "Forecasting Tourist Arrivals: Nonlinear Sine Wave or ARIMA?" Journal of Travel Research, vol. 36, pp. 79-84.

6. Cundiff, Kirby R. (2000), "Homicide Rates and Substance Control Policy," Department of Business Administration and Economics, Hillsdale College, Working paper. Available at http://www.independent.org/publications/working_papers/article.asp?id=745

7. DeFina, Robert H and Thomas M. Arvanites, (2002) "The Weak Effect of Imprisonment on Crime: 19711998", Social Science Quarterly, vol. 83, pp. 635-653.

8. Donohue, John J. and Steven D. Levitt, (2001) "The Impact of Legalized Abortion on Crime," The Quarterly Journal of Economics, vol. CXVI, issue 2, pp. 379-420.

9. $\quad$ Friedman, Milton, (1990), “An Open Letter to Bill Bennett," Freedom Daily, the Future of Freedom Foundation, April 1990. Available at http://www.fff.org/freedom/0490e.asp

10. Friedman, Milton (1991), “The War We Are Losing” Available at http://www.druglibrary.org/special/friedman/war_we_are_losing.htm

11. Johnson, Rutherford (2012), "The Choice Wave: An Alternative Description of Consumer Behavior", Research in Business and Economics Journal. Available at http://www.aabri.com/manuscripts/11865.pdf

12. Levitt, Steven D. (2004), "Understanding Why crime Fell in the 1990s: Four Factors that Explain the Decline and Six That Do Not," Journal of Economic Perspectives, Volume 18, November 1, pp. 163-190.

13. Kuziemko, Ilyana and Levitt, Steven D. (2004), “An Empirical Analysis of Imprisoning Drug Offenders," Journal of Public Economics, 88, pp. 2043-2066.

14. Lochner, Lance, (2004), "Education, Work, and Crime: A Human Capital Approach", International Economic Review, vol. 45, no.3, pp. 811-843.

15. Rose, Dina and Todd Clear, (1998), "Incarceration, Social Control and Crime: Implications for Social Disorganization Theory," Criminology, 36 (4), pp. 441-479.

\section{DATA APPENDIX}

United States Bureau of Justice Statistics (http://www.fbi.gov/about-us/cjis/ucr/ucr/)

U.S. Department of commerce, Bureau of Economic Analysis (http://www.bea.gov/itable/index.cfm)

Centers for Disease Control (www.CDC.gov)

United Nations Department of Economic and Social Affairs (www.unstats.un.org)

National Criminal Justice Reference Services (ncjrs.gov)

Drug Enforcement Agency (DEA) (www.justice.gov/dea) 